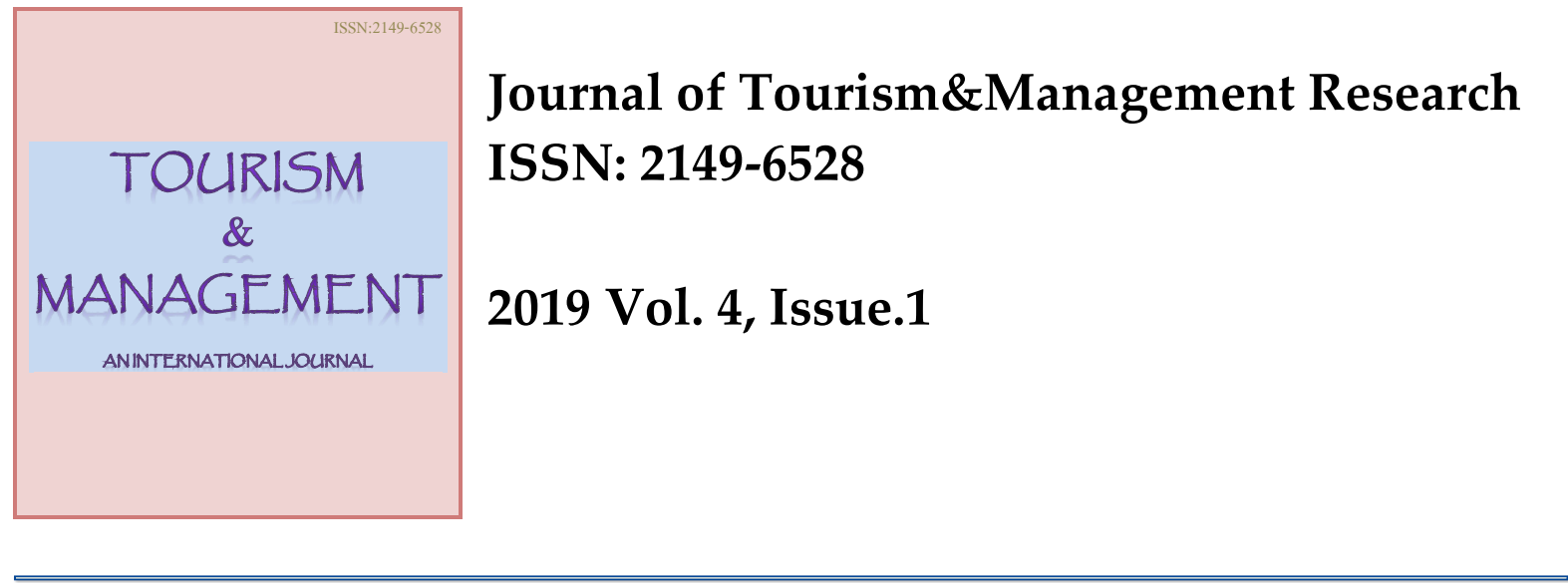

\title{
Exploring the relationship between travel motivations and preferred tourist attractions: A case of New Zealand and The United Kingdom
}

\begin{abstract}
The paper seeks to explore the role specific attractions play in bringing tourists to destinations. The paper also seeks to find out whether a destination projects itself differently to different source markets. Using content analysis, the paper applies Pearce's travel career pattern model and McKercher's attractions hierarchy framework to consider the motivations of travellers and the specificity of the attractions they seek to visit. New Zealand and the United Kingdom are used as destinations. Results indicate that less experienced tourists, mostly influenced by Pearce's outer layer motives, are largely attracted by specific attractions. Experienced travellers, mostly driven by Pearce's core motives, are interested in a range of generic attractions. Destinations project themselves differently to source markets based on the needs and the characteristics of the tourists, even though recently the destinations are moving towards promoting several generic attractions rather than focusing on a few popular attractions.

Keywords: Attractions, Travel career pattern, Attraction's hierarchy, United Kingdom, New Zealand.
\end{abstract}

JEL Classifications: L83, D91, M31.

Submitted: 04.12.2018; Accepted: 24.02.2019

Zandivuta Kankhuni. PhD student (Corresponding Author). School of Hotel and Tourism Management, The Hong Kong Polytechnic University Hong Kong \& Department of Hospitality Management, Mzuzu University, Malawi.+852 55720076.

Email: zandi.kankhuni@connect.polyu.hk

Cecilia Ngwira, PhD student. School of Hotel and Tourism Management, The Hong Kong Polytechnic University, Kowloon Hong Kong \& Department of Tourism, Mzuzu University, Malawi. +852 55138917. Email: cecilia.ngwira@connect.polyu.hk 


\section{Introduction}

It is assumed that attractions are very essential to the very existence of tourism so much so that the latter cannot be imagined without the former (Lew, 1987). It is "perhaps, deceptively self-evident that tourist attraction is important for the tourist industry and the analysis and development of tourism" (Pearce, 1991, p. 47). Destination Management Organizations (DMOs) have directed significant amount of resources towards the improvement of current and building of new attractions in a quest to develop and promote tourism (Truchet et al., 2016). The common belief is that without attractions, tourism cannot take place since tourists cannot visit in the absence of attractions. Thus attractions, in their different forms, are the raison d'être for tourism (Edelheim, 2015). This, in a way, is a manifestation of the supplyside "if you build it, they will come" approach to attracting tourists (McKercher, 2017; Norris, 2003). The investments in attractions have sometimes been without the anticipated gains (Rosentraub \& Joo, 2009). In view of the foregoing, this paper addresses the question: what is the role of attractions? Is it to attract tourists or, as Crompton (1979) contended, to simply satisfy their needs?

Despite extensive literature on tourist attractions, a dearth in literature still exists on the influence of tourist attractions on tourist services (Truchet et al., 2016). Indeed, Swarbrooke (2002) opines that much as attractions are the primary motivators for tourist visits and form the core of the tourism product, they are not well understood. But are travellers motivated to visit specific attractions or a constellation of them? McKercher (2016a) asks. He opines that the relationship between generic and specific motivations on the one hand and the specificity of attractions sought by tourists on the other hand is more complex. To further understand this complex relationship, the current study considers the motivations of travellers from the United States of America (USA), Germany, Australia and China as source markets and the specificity of the attractions and destination attributes they seek to visit in the United Kingdom and New Zealand as destinations by utilizing attractions hierarchy framework and travel career pattern by McKercher (2016b) and Pearce (2005) respectively. The study also seeks to find out how the two destinations project themselves to the source markets and whether there are any similarities or differences in the way the four markets view each of the two destinations.

\section{Literature review}

\subsection{Attractions}

There seems to be a lack of a rigorous and straight-to-the-point definition of attractions that is applicable to all attractions (Aspridis, Sdrolias et al., 2015; Leiper, 1990; Pearce, 1991; Swarbrooke, 1995). This lacking arises mainly due to two reasons: firstly, there is currently no consensus on the number of visitors that must travel to a site before it can be categorized as an attraction and secondly, the purpose for visiting a site may determine whether or not the site can be categorized as an attraction (Aspridis et al., 2015; Swarbrooke, 1995). Nevertheless, "a theoretical and conceptual understanding of tourist attractions requires a precise definition in order that the range of applicability of a theoretical statement or principle may be quickly gauged" (Pearce, 1991, p. 46). Such being the case, attempts have been made by various authors to define a tourist attraction.

Middleton and Clarke (2001) define an attraction as a permanent resource managed for visitor enjoyment, entertainment and education. Swarbrooke (1999) reports the Scottish Tourism Board as having defined an attraction as a permanent establishment that draws tourists and day visitors. These definitions both do not consider the fact that dark tourism sites such as places of major disasters and prisons are also attractions (Leask, 2010). Pearce (1991, p. 46) refer to a tourist attraction as a "named site with a specific human or natural feature which is the focus of visitor and management function". Pearce argues that good scenery is not a tourist attraction but a named, managed and well used a scenic lookout is. However, 
tourism resources such as intangible heritage which might transcend space and time would hardly fit into this definition.

Perhaps in pursuit of an almost all-encompassing definition, Lew (1987) describes attractions as all those elements of a "non-home" place that draw travellers away from their homes. These elements, Lew further states, include landscapes to observe, activities to participate in, and experiences to remember. Lew (1987), however, cautions that sometimes setting boundaries in terms of what attractions are and what they are not, is difficult since elements such as transportation, accommodations, or even tourists themselves can become attractions. Further, it has been argued that it is the market that decides what an attraction is since attractions could not be called as such if tourists did not consume them (Leiper, 1990). We adopt Lew's (1987) definition as a working definition for the study.

\subsection{Classification of Tourist Attractions}

Attractions have been classified simply as primary, secondary and tertiary: primary attractions act as the tourists' demand generators whereas secondary and tertiary attractions are many, substitutable and have a local appeal (McIntosh \& Goeldner, 1990; Mill \& Morrison, 1985). Bull (1991) posits that attractions act as an intrinsic part of a trip, a major motivation to visit a place as well as a discretionary activity that tourists engage in at the destination. Lew (1987) classifies attractions into three categories namely: cognitive, organizational and ideographic. Cognitive perspective corresponds to how people perceive an attraction as either being risky or not when tourists are experiencing them. Organizational perspective refers to the attractions attributes such as location, magnitude, capacity and whether the attraction is temporary or permanent. Lastly, the ideographic attraction perspective refers to the way attractions are named as well as how unique they are to be given that name.

Weaver (2006) classify attractions based on their orientation, ownership, spatial configuration, scarcity, authenticity, status, accessibility, market and carrying capacity. Leask (2010) proposes a classification system for tourist attractions that categorizes attractions depending on their nature, type of ownership, market attributes and resultant products. McKercher (2016b) presents a six tier product taxonomy that can be applied to satisfy tourists' needs. McKercher (2016a) links the product taxonomy to a six tier product hierarchy termed attractions/needs relationship framework.

The framework is aimed at analysing how an individual attraction stands in pulling tourists to a particular destination (see section 2.5). Klarić (2017) suggests classifying attractions in two three categories - natural heritage, cultural heritage (man-made attractions), and other attractions (tourist infrastructure and events). Going by McKercher's (2016b) and Klarićs (2017) classifications, the study assumes that whatever a tourist consumes in a destination is an attraction regardless of whether it is officially named, priced or managed (Leiper, 1990).

\subsection{The Role of Attractions in Destinations}

Despite attractions being considered catalysts for regional development, research on attractions is still insufficient (Leask 2010; Connell et al., 2014; Ram et al., 2016; Truchet et al., 2016). Leask (2010) states that the importance of attractions can be appreciated from various angles - those of individual tourists, individual resources and in relation to the role of the attraction in destination development. An attraction may be developed guided by the desire to conserve and enable public access to a resource (Leask, 2010) or as a means to economic regeneration, especially in rural areas with limited development options (Huang et al., 2016).

Sharpley (2009) notes that much as a number of factors guide the successful development of tourism destinations, the primary objective remains providing what are collectively known as visitor attractions. Seminal works on the concept of tourist attractions identify them as first 
power and energizers of tourism and that without attractions tourism services would not flourish (Gunn, 1972, p. 24). Of course some would wonder as what we could call people visiting their friends and families, attending events or studying in places far away from home. Each of these is a reason to travel and in this regard friends and family, an event and a foreign institution of learning would be referred to as an attraction (Edelheim, 2015). The foregoing discussion shows that perhaps to understand the potency of attractions to attract tourists it is necessary to consider what motivates people to travel.

\subsection{Travel Motivation and Behaviour}

Even though travel motivation is one of the important determinants of travel behaviour (Crompton, 1979), tourism researchers are yet to fully understand the concept (Huang \& Hsu, 2009). Understanding what motivates people to travel will help in the development of facilities in a destination area as it helps planners to better anticipate tourist behaviours (Cha, et al., 1995; Fodness, 1994).

Extant literature on the concept shows that only limited new theoretical themes have emerged from a long period of research (Huang \& Hsu, 2009), among which are extensions of the Hierarchy of Needs (Maslow, 1970) and Allocentrism/Psychocentrism model (Plog, 1974; 1987; 2001). Maslow argued that all human needs can be arranged on a five-step hierarchy/pyramid. Pearce (1982) applied Maslow's idea to tourist motivation and behaviour and concluded that tourists visit vacation destinations with the ultimate aim of "fulfilling selfactualization, love and belongingness, and physical needs in that order of importance" (Huang \& Hsu, 2009, p. 288). One important travel motivation framework - the travel career ladder (TCL) (Pearce, 1982), was developed based on Maslow's hierarchy. It suggests that there are five different ascending categories of needs/motivations influencing tourist behavior (Ryan, 1998). Like a career goal in tourist behavior, the framework suggests that with accumulated travel experience tourists seek fulfilment of higher needs (Pearce, 1991).

Iso-Ahola (1982) suggests a social psychological model which states that engagement in leisure is as a result of an interplay of two factors: to escape from mundane environments and to seek personal/interpersonal opportunities (Doran et al., 2015). Dann's (1977) theory of anomie and ego-enhancement (Push and Pull theory) suggests that people leave their usual environments to run away from the stress of their daily lives (also referred to as anomie) in pursuit of ego-enhancement or new experiences.

To this end, several motives have been identified in travel and tourism (Moutinho, 2001; Pearce \& Lee, 2005; Sung et al., 2000). Despite differences in the presented theories, all agree that travel motivation is a product of human psychological and biological needs (Leong et al., 2015). This paper seeks to relate the push and pull concepts by considering how destination attributes and experiences that tourists seek can explain profiles and motives of the tourists.

\subsection{Theorizing the Attraction-tourist Relationship}

The current study utilizes the attractions hierarchy framework by McKercher (2016b) in figure 1 below to examine the role of attractions in influencing tourists' travel decision. It seeks to address the question 'can the attributes of and activities offered in a destination reflect people's decision to visit?' The framework posits if needs are specific, then only few individual attractions will satisfy the needs. However, if needs are generic, then either a selection of substitutable attractions within a specific attractions group or different types of unrelated attractions can provide a satisfying experience. 
Nature of needs

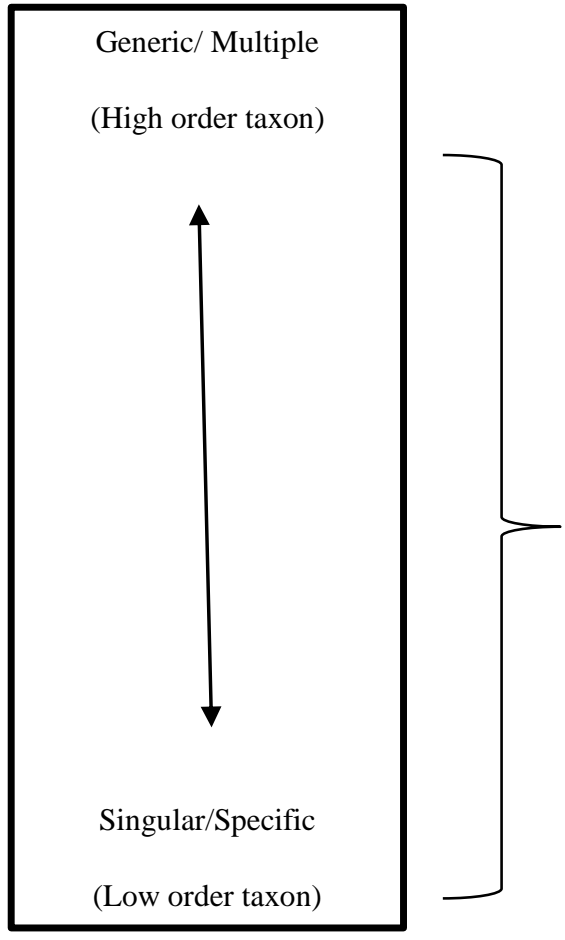

Nature of attraction

High order taxon (Need

family with many subsets

and substitutable

activities)

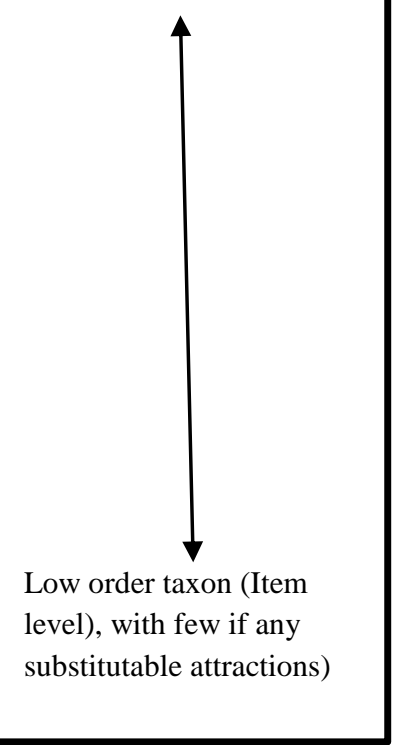

Role of Individual

Attraction in

attracting tourists

Low

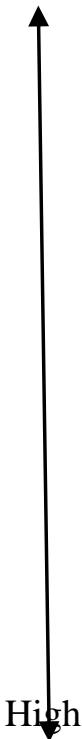

Figure 1. Role of Individual attractions in drawing tourists to a destination.

Source: McKercher (2016b).

Closely related to the specificity of the tourist needs in determining which attractions to visit is the accumulated travel experience of the individual. The travel career pattern (TCP) framework developed by Pearce and his colleagues (Lee \& Pearce, 2002; Pearce, 1988; Pearce, 2005; Pearce, 2011; Pearce \& Lee, 2005) asserts that travel motivation is influenced by travellers' experience and life-stage factors. The framework, which adapts and extends the TCL approach, distinguishes travel motives into three categories: core motives, middle layer motives and outer layer motives (Pearce, 2011). Travel motives of escape/relaxation, novelty, relationship enhancement and self-development are important and core to all travellers regardless of travel experience (Wu \& Pearce, 2014). Middle layer motives are associated with travellers who are in the pursuit of self-actualization and seeking to be closer to the local environment. Outer layer motives such as recognition, stimulation, romance and nostalgia are comparatively highly valued by those with lower travel experiences. Similar to Maslow's theory, the TCL contends that lower level needs should be satisfied before individuals can pursue the fulfilment of higher level needs.

However, the TCP downplays the importance of such a hierarchical approach and instead focuses on the changing nature of travel motivations (Zhang \& Peng, 2014). Indeed scholars have cautioned that the common assumption in travel motivation studies that needs ascend only from the basic to the advanced level is misguided (Kim et al., 1996; Ryan, 1998; Ryan, 1998). Wong and Musa (2014) argue that travellers may start at any level of the TCL going up or down depending on their prior travel experiences and knowledge in the activity of travel interest. According to Pearce (2011), a good travel motivation theory should build upon previous work and is developmental and dynamic in its approach to explaining travel motivations. The TCP meets these requirements (Ryan, 1998; Zhang \& Peng, 2014) that is 
why the current study adopted it to understand the relationship between travel motivation and tourist attractions and activities.

McKercher and Koh (2017) tested the two models using Singapore as a case study, providing insightful findings. However, it should be noted that Singapore is a small destination with relatively a small tourist attraction base, thus it was considered important to situate the study in bigger destinations so as to enhance the applicability of the findings. That is why the current study sought to address the question in the context of the UK and New Zealand which are bigger destinations, with diverse ranges of attractions.

As explained later in the methodology section, the study used secondary data to achieve its objectives. McKercher and Koh (2017) have pointed out the drawbacks of using secondary data in research of this nature. One, it should be noted that the two destinations do not present their attractions on the specificity spectrum as the attraction's hierarchy model presents them, thus the hierarchy can only be inferred from the data. Two, tourists could be motivated by different needs at different times of the year (e.g. going on an adventurous skiing holiday in winter, but then proceeding to visit cultural heritage attractions with family during their summer holiday) and life stages that are not reflected in the data under consideration. Thus it could be considered a futile attempt to discern insightful relationships between visitor reports and a concept so nuanced as travel motivation. However, Backman et al. (1995) argue that motivations are associated with individual basic needs for engaging, for example, in activities. Furthermore, in a work on tourists' motivation, Krippendorf, as cited in Moscardo et al. (1995, p. 109) opines that many of the motives stated by tourists are not specific hence tourists may address them with a variety of satisfiers. Thus, activities could be the critical connectors between tourist motivation and the choice of a destination or attractions (Moscardo et al., 1995).

\section{Methodology}

This paper uses the publicly available data produced by the national tourism authorities of New Zealand and United Kingdom (Tourism New Zealand, 2017), and British Tourist Authority (VisitBritain, 2017) to achieve the stated objectives. The British Tourist Authority produces, among other publications, three annual publications - market and trade profile, market snapshot and an aviation profile, for each of its important source countries. The New Zealand Tourism Board compiles source market insight reports every six months on each of its important source markets. It also publishes visitor infographics which provide key insights on tourist demographics and behaviour on the source markets. Also, the organization releases special interest and sector research reports on activities potential tourists have interest in and could drive their travel decisions. Such comparatively comprehensive quantitative and qualitative reports produced and made publicly available by the two destinations motivated the choice of the same as fitting destinations for the study. Information from newspapers, news sites, magazines and trade and company publications was also used. These were chosen based on their relevance in terms of how well known they are, sources used in their articles/reports and involvement in the industry.

The source markets were chosen because of their importance to the destinations in terms of arrivals, expenditure and potential for growth as shown by current market trends. The United States of America is the second largest source market to the United Kingdom in terms of arrivals followed by Germany which is also the second most important source market in terms of expenditure (VisitBritain, 2017). Chinese tourists were among the highest spenders in the period under consideration. Australia, even though it ranks tenth as a source market in terms of arrivals to the United Kingdom (VisitBritain, 2017), is the largest source market in terms of arrivals to New Zealand, seconded by China (Tourism New Zealand, 2017). Germany is New Zealand's second largest market in Europe whereas the USA is the third largest source market in terms of arrivals globally (Tourism New Zealand, 2017). 
It has been argued that secondary data analysis is an acceptable method that can be used when primary data is not available only and only if the reliability, sensitivity, validity and fitness requirements of the research purpose at hand are met (McKercher \& Chan, 2005). These requirements were met since the data are gathered by the tourism authorities of the two destinations for, among others, marketing and destination management purposes. Such purposes are of strategic importance that normally require rigorous research methodologies. Content analysis was used to situate travellers' needs/motivations in Pearce's career ladder pattern framework on the one hand, and the attractions, activities and other destination attributes sought in McKercher's attraction's hierarchy on the other.

\section{Results}

Findings are discussed per destination. Under each destination, a summary of statistical details about visitors from each source market are given in a table (Tables 1 and 2) accompanied by qualitative information on the leisure travellers from that source market. Details like visitor perceptions about the destination and drivers (travel motivations) are analysed in relation to tourists' travel patterns within the destination, average length of stay and activities pursued in the destination. Such analyses are done separately for each source market in line with the travel career pattern model and the attractions hierarchy framework.

\subsection{The United Kingdom}

The United Kingdom consists of Great Britain, north-eastern part of the island of Ireland and other smaller islands. For ease of analysis, data used here were sourced mainly from VisitBritain's website and publications. VisitBritain is the name used by the British Tourist Authority, the organization charged with the responsibility of promoting Great Britain's tourism. Table 1 below presents the summary of information on the United Kingdom's four source markets alluded to above.

Table 1: Visitor profile of 4 source markets.

\begin{tabular}{|c|c|c|c|c|}
\hline & United States & Germany & Australia & China \\
\hline Arrivals (2016) & $3,455,482$ & $3,341,137$ & 981,774 & 260,431 \\
\hline \multicolumn{5}{|l|}{ Trip purpose $(\%)$} \\
\hline Holiday & 45 & 46 & 40 & 46 \\
\hline VFR & 25 & 23 & 41 & 22 \\
\hline & 40 & & & $70^{*}$ \\
\hline $\begin{array}{l}\text { Percentage of } \\
\text { first time visitors }\end{array}$ & & 25 & 38 & \\
\hline \multicolumn{5}{|l|}{ Travel companions (\%) } \\
\hline Alone & 19 & 14 & 20 & 14 \\
\hline With spouse/partner & 66 & 62 & 54 & 72 \\
\hline With friends & 10 & 10 & 14 & 13 \\
\hline Largest age group & $49+$ & $45+$ & $45+*$ & $25-44$ \\
\hline Percentage of males & 48 & 47 & & 50 \\
\hline Average length of stay & 8 & 6 & 13 & 20 \\
\hline Visitor perception & $\begin{array}{l}\text { Mostly associated } \\
\text { with cultural } \\
\text { attractions; } \\
\text { educational; ease }\end{array}$ & $\begin{array}{l}\text { Associate the } \\
\text { UK with } \\
\text { contemporary } \\
\text { culture \& }\end{array}$ & $\begin{array}{l}\text { Destination } \\
\text { associated with } \\
\text { museums, films } \\
\text { and music. }\end{array}$ & $\begin{array}{l}\text { Cultural } \\
\text { heritage; } \\
\text { contemporary } \\
\text { culture; }\end{array}$ \\
\hline
\end{tabular}




$$
\text { of getting around }
$$

sport; built

heritage;

museums and

music

Travel patterns

$$
\begin{aligned}
& \text { Frequent visitors } \\
& \text { Long stays }
\end{aligned}
$$

Drivers

Activities

Sightseeing of
popular
buildings/museums
Shopping
Going to a pub

Frequent visits, relatively long stays

$\begin{array}{ll}\begin{array}{l}\text { The location/being } \\ \text { there }\end{array} & \begin{array}{l}\text { Sun, warm } \\ \text { weather; }\end{array} \\ \text { Get away from } & \begin{array}{l}\text { leaving } \\ \text { everyday } \\ \text { normal, everyday }\end{array} \\ \text { life } & \begin{array}{l}\text { behind; } \\ \text { Spend time with }\end{array} \\ \text { family and friends } & \begin{array}{l}\text { finding new } \\ \text { strength; }\end{array} \\ \text { To relax/rejuvenate } & \begin{array}{l}\text { having fun } \\ \end{array}\end{array}$

Shopping was number one; going to the pub; popular built heritage sites; visiting parks/gardens
Expect their trip there to be educational and fascinating.

Frequent, long stays. On multinational tour in Europe

Being with friends and family; looking for challenges and inspiration; cultural heritage

\section{Social}

Visiting a pub; meeting the locals; Shopping; Unique attractions. status/prestige; selfdevelopment

museums; symbolic elements (royal family, Harry Potter)

\author{
Shopping \\ (British brands); \\ parks and \\ galleries; \\ heritage sites; \\ British football \\ teams.
}

Note: *=2015 data. Source: Tourism New Zealand (2017) and VisitBritain (2017).

United States of America (USA) - The USA was the second largest inbound source market for the UK in terms of arrivals and the most valuable source market for visitor spending in 2016 (VisitBritain, 2017). 70\% of the travellers from the USA came for pleasure: $45 \%$ for holidays and $25 \%$ to visit friends and relatives. American visitors were older (49+ years) than the average inbound traveller. About $60 \%$ of the American travellers were repeat visitors. In terms of travel motivation, a majority of Americans reported that they travel abroad because they want to get away from normal, everyday life, to relax and to spend time with family and friends. Ease of getting around the destination was also a reason Americans chose the UK. These reasons correspond to Pearce's core and middle layer motives. It is perhaps not surprising that generic activities such as visiting museums, shopping and patronizing pubs were popular among the Americans.

However, according to Hilton Resorts and Hotels (2017), 57\% of American passport holders feel that passport stamps are a "badge of honour", suggesting the inspirational nature of international travel to the Americans. Also, VisitBritain (2017) states that one motive for travel among Americans is to go to particular location so that they can have the feeling of "being there". Indeed, it was noted that popular cultural attractions (especially built heritage) was a strong motivator for American travellers to choose the UK (ibid). With 40 percent of the travellers being first-time travellers, a significant portion of American travellers to the destination could be said to be less destination-aware. Thus the American inbound market into the UK is a combination of roughly two segments - those moved Pearce's core motives preferring generic attractions, and those driven by Pearce's outer layer motives attracted to popular attractions. 
Germany - Germany was the third most important source market for the UK for arrivals and second most important for expenditure in 2016. 75 percent of German travellers to the UK were repeat visitors in 2016. For their travel abroad, Germans are mostly motivated by the need to relax, find new strength and have fun (Lohmann, 2015). Research shows the Germans do not view the UK as a family-friendly destination mostly because they consider it as too expensive to families and also because the feel the destination does not offer much children entertainment attractions, specializing rather in culture and history (VisitBritain, 2017). Germans were interested in adventurous and outdoor activities like walking and cycling. They are interested in learning about the history of the places they visit and prefer to go off the beaten path and stay away from tourist crowds, adjusting their itinerary as they go (VisitBritain, 2017) Thus, it seems the Germans are interested mostly in generic attractions, as per McKercher's attraction's hierarchy model. One would safely argue then that, for the German travellers, attractions or destination attributes played the role of need satisfiers, serving as a means to an end. Destination experiences mattered more than specific attractions. Indeed, VisitAberdeenshire (2017, p. 2) states that "Germans love to travel. For them, travelling is a necessity: a reward for their hard work and an escape from stresses of life".

Australia - Australia is a maturing and tenth inbound source market for the United Kingdom. To a majority of the Australians, visiting the UK is like going home, pursuing ancestral, social and family links that they would not find elsewhere (VisitBritain, 2017). About $13 \%$ of the inbound travellers from Australia were British citizens. Furthermore, over a third of travellers from Australia in 2014 stayed with family and friends while visiting the UK. Much as the travellers from Australia are motivated by a combination of Pearce's core motives (relationship with family/friends) and outer layer motives (challenging experiences), their activities in the destination mostly reflected the former to be greater than the latter since popular activities were aimed at relationship-enhancement: spending time with the locals and attending communal/family events. Indeed, VisitBritain (2017) notes that visitors who went to a religious building while visiting their friends and/or families may have done so to attend a funeral, wedding or christening, hence mostly visiting places that are not typical tourism hotspots (VisitScotland, 2018). Thus attractions could be said to have played a secondary role to attracting Australian travellers to the UK.

China - The average Chinese visitor is younger than the average international visitor to the United Kingdom. About $70 \%$ of the visitors from China were first-time visitors, meaning that the Chinese market is likely less destination-aware. To the Chinese, going on a holiday is an opportunity to show one's social status and to learn about the world (VisitBritain, 2017). This shows that Chinese travellers to the UK are mostly motivated by Pearce's middle- and outer-layer motives. It is perhaps unsurprising, therefore, to note that shopping is the number one activity for Chinese travellers to the UK, buying mostly specific British brands. The Business Traveller (2018) reports that the Chinese are less interested in the typical UK tourism hotspots such as museums and historic sites. The Chinese are also much interested in attending UK education institutions and attending English football team games. Indeed, students made up $42 \%$ of the total nights spent by Chinese tourists in the UK. Using the attraction's hierarchy model by McKercher (2016a), one can safely argue that the Chinese are largely attracted by specific attractions since both their needs and appealing attractions are low-order on McKercher's model.

\subsection{New Zealand}

Tourism New Zealand is the trading name of the New Zealand Tourism Board, a body charged with the responsibility of promoting New Zealand as an international tourism destination. Table 2 below presents information about the United Kingdom's four source markets. 
Table 2: Visitor profile of 4 source markets.

\begin{tabular}{|c|c|c|c|c|}
\hline & United States & Germany & Australia & China \\
\hline Arrivals* & 321,400 & 104,256 & $1,360,000$ & 404,224 \\
\hline \multicolumn{5}{|l|}{ Trip purpose (\%) } \\
\hline Holiday & 62 & 74 & 39 & 77 \\
\hline VFR & 19 & 12 & 40 & 11 \\
\hline $\begin{array}{l}\text { Percentage of } \\
\text { first time visitors }\end{array}$ & 81 & 82 & 45 & 91 \\
\hline $\begin{array}{l}\text { Travel companions } \\
(\%)\end{array}$ & 54 & 54 & 72 & 54 \\
\hline $\begin{array}{l}\text { With partner/spouse } \\
\text { With friends }\end{array}$ & 24 & 31 & & 24 \\
\hline Largest age group & $40+$ & $25-54$ & $25-54$ & $40-60$ \\
\hline Percentage of males & 50 & 58 & 57 & 50 \\
\hline Average length of stay & 13 & 44 & 11 & 8 \\
\hline $\begin{array}{l}\text { Leisure visitor profile } \\
\text { Perception }\end{array}$ & $\begin{array}{l}\text { Clean \& } \\
\text { unpolluted; } \\
\text { affordable } \\
\text { destination }\end{array}$ & $\begin{array}{l}\text { Landscapes \& } \\
\text { scenery; clean \& } \\
\text { unpolluted; affordable } \\
\text { destination }\end{array}$ & $\begin{array}{l}\text { Clean \& } \\
\text { unpolluted } \\
\text { environment; } \\
\text { landscapes and } \\
\text { scenery }\end{array}$ & $\begin{array}{l}\text { Natural } \\
\text { scenery; green } \\
\text { environment; } \\
\text { contemporary } \\
\text { life }\end{array}$ \\
\hline Travel patterns & $\begin{array}{l}\text { New travellers; } \\
\text { long stays. }\end{array}$ & $\begin{array}{l}\text { Novice travellers; } \\
\text { very long stays. } \\
\text { Arrange the trip as } \\
\text { they go }\end{array}$ & $\begin{array}{l}\text { Both first-time } \\
\text { and repeat } \\
\text { visitors; repeat } \\
\text { visitors are } \\
\text { explorers }\end{array}$ & $\begin{array}{l}\text { First-time } \\
\text { visitors on } \\
\text { short, dual- } \\
\text { destination } \\
\text { tours }\end{array}$ \\
\hline Drivers & $\begin{array}{l}\text { Status; } \\
\text { Personal } \\
\text { challenges; } \\
\text { Self- } \\
\text { development; } \\
\text { Feeling } \\
\text { happiness; } \\
\text { Relaxation }\end{array}$ & $\begin{array}{l}\text { Aspiration/sense of } \\
\text { achievement; }\end{array}$ & $\begin{array}{l}\text { Relaxation; } \\
\text { experiencing } \\
\text { (other) local } \\
\text { cultures; } \\
\text { adventure }\end{array}$ & $\begin{array}{l}\text { Project } \\
\text { 'face'/image; } \\
\text { get away; feel } \\
\text { alive in the real } \\
\text { world }\end{array}$ \\
\hline Activities & $\begin{array}{l}\text { Observing } \\
\text { wildlife; } \\
\text { walking/hiking } \\
\text {; beach; } \\
\text { cultural } \\
\text { experience; } \\
\text { museum/art } \\
\text { gallery. }\end{array}$ & $\begin{array}{l}\text { Walking/hiking/tramp } \\
\text {; } \\
\text { Observing wildlife; } \\
\text { visiting the beach; } \\
\text { national parks }\end{array}$ & $\begin{array}{l}\text { Observing } \\
\text { wildlife; } \\
\text { hiking/walking } \\
\text {; national parks }\end{array}$ & $\begin{array}{l}\text { Observing } \\
\text { wildlife; } \\
\text { hiking/walking } \\
\text {; Maori cultural } \\
\text { experience; } \\
\text { national parks }\end{array}$ \\
\hline
\end{tabular}

Notes: *=Year ending August 2017. Source: Tourism New Zealand (2017) and VisitBritain (2017).

United States of America - The USA is New Zealand's third largest international market. In 2017, 62\% American travellers to New Zealand visited for holidays while 19\% came to visit friends and family. Travelers in the younger age category (25-54 years) were mostly 
motivated by the need to "feel good about themselves" and "get an adrenaline rush" which can be categorized under Pearce's outer layer motives, so they seek activities that specifically meet such needs such as hiking, visiting the beach and observing wildlife. Those in the older age group, who were in majority, were motivated by the yearning for learning, exploration and relaxation which are Pearce's core and middle-layer motives and thus mostly visit museums and art galleries and seek to experience the Maori culture. Considering McKercher's hierarchy, the two groups are on opposite ends of hierarchy, with the younger travellers motivated by specific needs whereas as the more senior travellers are motivated by generic needs.

Marketing messages to the USA market are centred on the opportunity to experience Maori culture, adventure, nature and wildlife and food and wine (Tourism New Zealand, 2017). Marketing activities have mostly involved influencer (celebrity) endorsements, videography and roadshows. Thus, in the case of New Zealand, American travellers are fascinated by a wide range of generic activities, rather a popular few. This could mainly due to the fact that the destination is considered a place that one goes to relax and rejuvenate (Tourism New Zealand, 2017).

Germany - Germany is the New Zealand's second largest tourist generating country in Europe and one that presents a number of opportunities (Tourism New Zealand, 2017). Germans consider New Zealand a clean and affordable destination, with a variety of outdoor experiences. Over $80 \%$ of the German visitors are visiting for the first time and are mostly driven by Pearce's outer-layer motives. $74 \%$ visited for holiday whereas $12 \%$ came to visit friends and family. A majority of the Germans are relatively younger and come for working holidays. Most of the visitors arrange their itineraries while travelling around New Zealand. Tourism New Zealand (2017) reports that the Germans have a strong tendency towards noncommercial attractions, preferring places that are not popular with group tours.

Thus, even though Germans are motivated by outer-layer motives, it seems they do not like to visit popular individual attractions in the destinations, but to explore a wide of generic attractions. Indeed, Tourism New Zealand (2017) points out that Germans visitors appreciate the destination's mix of natural wonders and cultural attractions. Perhaps this could be because the Germans are avid travellers and deep explorers as stated by Nigel Richardson, a contributor to Telegraph Travel (2017), "Whenever you think you've reached somewhere few people have been, and are feeling smug about it, a campervan will appear and eight Germans will spill out, looking as if they've been to a million such places".

Australia - Australia is New Zealand's largest source market, accounting for almost $50 \%$ of all inbound travellers (Tourism New Zealand, 2017). Independent professionals constitute over half of the Australian arrivals. About 60 percent of Australian visitors to New Zealand are repeat visitors. Pearce's core and middle layer motives seem to be the drivers. Tourism New Zealand (2017) states that Australians are likely to visit 4 times for holiday in their lifetime, perhaps because of the destination's proximity to Australia. Being destination-aware, the visitors are mostly interested in substitutable attractions/activities such as walking, hiking or visiting national parks. Tourism New Zealand's marketing activities for Australia aim at attracting Australians to the less travelled regions of the destinations, promoting a wide range of activities from skiing resorts to golfing. To a significant extent, this shows that the Australians are not specifically drawn by specific attractions to New Zealand.

China - China is New Zealand's second largest market. Chinese visitors to New Zealand stay the shortest among the four markets considered. Over $91 \%$ of the visitors were visiting for the first time and a majority had travelled in groups, combining New Zealand and Australia in the same trip. However, Tourism New Zealand (2017) reports that the Chinese market is shifting towards free independent travellers (FITs) as the Chinese gain confidence in organizing their own travel. Pearce's outer layer and core motives were the motivational factors for the most of the Chinese visitors. The Chinese market is a tale of two segments: the 
group tour market that wants to visit many places in a short period of time and the FITs that arrange their trip as they go and look for opportunities to enrich themselves. The former is likely going to be drawn by popular attractions just "to tick a box" whereas the latter's needs will likely be satisfied by diversified generic attractions. In agreement with the former, a study by Sun (2013) found out that Chinese visiting New Zealand were less interested in cultural activities and visiting museums.

\subsection{Source Market Comparison}

For the UK, it was observed that Americans visit mostly because they want to visit family and friends and also because they want to attain a "badge of honour", hence there is pursuit of specific iconic attractions on the one side of the product taxonomy and a need to experience generic attractions on the other. Australians consider the UK as an extension of home, hence attractions play a secondary role in influencing their visit. For Germans, the motives for their visit are mostly core on Pearce's travel career pattern, but they still pursue specific attractions. Unlike the Americans, Germans do not consider the UK a family-friendly destination, due to cost and attraction considerations. The Chinese are motivated to visit by a combination of Pearce's middle and outer layer motives and are, resultantly, drawn by specific attractions.

Similarly, there are variations in the way the markets regard New Zealand as a destination. The American and Chinese markets are each a tale of two segments: a younger age market that is motivated by Pearce's outer layer motives and hence find specific attractions appealing, and an older market motivated mostly by core motives. The latter gets satisfaction from high-order attractions on the need-product taxonomy. The German market again is dominated by two segments, though not in the same equal proportion as the other two markets. A smaller segment consists of younger travellers who visit for longer working holidays. Motivated by high order needs, an older traveller segment is interested in a range of generic off the beaten track type of attractions. Australians are frequent deep explorers who visit for a wide range of attractions.

\subsection{Destination Comparison}

United Kingdom - The UK promotes itself as a home of amazing moments, riding on the back of its rich culture/history and countryside. VisitBritain's marketing initiatives in the USA focus on the popular attractions that the UK has. In 2013, for instance, VisitBritain partnered with Bloomingdales to promote to the department store's customers travel packages inspired by British landmarks ("Bloomingdale's Loves Great Britain”, 2013). VisitBritain's marketing initiatives in Australia aim at presenting the destination as a combination of different attractions. VisitBritain's country manager in Australia has stated that:

\section{By showcasing the sheer diversity of amazing cultural, heritage and countryside moments found across our nations and regions, we want to inspire Australians to put Britain at the top of their "must-go-now" destination and book a trip to come and discover their own amazing moments. (Mayling, 2016, para. 5).}

VisitBritain reports that Germans do not rate the destination highly on natural beauty but consider it their top destination for cultural heritage and education (Lenz, 2016). Thus the destination's key messages are centred on the market's perceptions, even though there have been efforts to convince the Germans to explore beyond heritage cultural sites and education institutions.

In China, VisitBritain builds its key messages around the idea that Chinese travellers love to visit famous landmarks. In 2015, for instance, VisitBritain used online platforms to invite the Chinese to create their own names for iconic British landmarks. However, the destination 
has taken note of the growth of the independent core-motive influenced traveller segment and is therefore promoting heritage and culture alongside shopping tourism, among others.

New Zealand - New Zealand promotes itself destination-wise as 100\% Pure New Zealand. This campaign seeks to invoke the "wholeness" of the destination in the mind of the potential visitor. Through influencer-endorsement, New Zealand wants to attract more of the Chinese FITs who stay long and are willing to go beyond the well-known tourist attractions, rather than packaged-tour travellers who want to quickly visit many places. Thus the destination wants to project itself as an amalgam of substitutable attractions, rather than a place of few iconic attractions.

Australia is New Zealand's closest and biggest market. The destination aims at driving brief visits that are spatially dispersed. The focus is on specific attractions such as New Zealand Cycle Trails (Tourism New Zealand, 2017). In the USA, how Tourism New Zealand promotes the destination is a reflection of the composition of the market. Recently, it has used a Hollywood star, Bryce Dallas, to promote it to a wide-ranging American audience, from those seeking specific adrenaline sports to those interested in the Maori culture.

Germany is a second-priority market for New Zealand. To speak about to-the German outbound market, which is dominated by backpackers who are looking for unconventional attractions, Tourism New Zealand uses social media, events and celebrity endorsements. In April 2015, for instance, Tourism New Zealand flew five Germany's Top Next Model contestants to New Zealand to participate in various activities and photo shoots ("Tourism New Zealand hosts Germany's Next Top Models," 2015).

China is a core priority market for New Zealand. Tourism New Zealand's marketing campaign in China, the Heart of the Long White Cloud, engaged Wu Ershan, a Chinese film director, and Shu Qiao, a food writer also from China, in showcasing the cultural, natural and outdoor experiences that New Zealand can offer. Thus, New Zealand is keen on attracting young FITs who are interested in generic attractions.

\section{Conclusion, Implications, and Limitations}

This study offers a few insights on the role of attractions and destination attributes in attracting tourists. Pearce's travel motivations applied differently to different segments of markets under consideration. The study also confirmed McKercher's attraction's hierarchy model, albeit with a few exceptions. Even though German travellers to New Zealand were less destination-aware, they opted to visit places that were not popular with group tours. In the UK, specific heritage attractions were popular with German tourists even though their needs seemed generic. Though we cannot be certain, perhaps the fact that a lot of young Germans who visited New Zealand went there on work visas could explain the first exceptional observation. One can also observe that that the two destinations are trying to project themselves as bundles of attractions, despite some markets' desire for specific popular attractions. As an extension, it has been observed that there are marked differences in traveller preferences among segments of the same source market insofar as attractions are concerned.

So, how do we reconsider role of attractions? Do they attract tourists? The answer is contextual. The context of the tourist, who they are, their travel experiences and travel motivations, etc. Context will also matter in how we define the attractions. McKercher's attraction's hierarchy model comes in handy here: Chinese tourists are looking for British designer brands to buy during their UK visits, whereas Germans are interested in culture in general. Both culture and designer brand shopping are attractions and they do attract tourists in this instance, but their places on the taxonomy are different. Additionally, it is important to dig deeper when one finds out that a group of tourists are interested in several attractions, lest misleading conclusions are made. Australians like to visit religious buildings in the UK, for example, not because they are primarily interested in religious attractions, but because these are places where they enhance their familial and friendship ties. This also brings in a new 
dimension to the promotion of tourism into a destination: instead of only promoting the existing attractions, religious buildings in this case, which are secondary attractions, DMOs could also focus on promoting events that would ultimately bring visitors to such attractions. VisitBritain can, for example, organize events where Australian tourists can trace their heritage or origins in the United Kingdom. Countries like Ghana and Senegal in West Africa have successfully established themselves as diaspora tourism destinations for AfricanAmericans using the same approach, for example.

Destination managers, marketers, politicians and other stakeholders ought to understand that much as attractions might attract tourists, the breadth of the attractions, the motivations and characteristics of the tourists and movement and visitation patterns of tourists while in the destination also matters. This could help destination authorities and enterprises understand what tourists are looking for and which attractions or destination attributes are favoured. Such understanding could help them make sound investment decisions in developing tourist attractions and devise cost-effective marketing strategies in promoting the attractions and enhancing tourist experiences in the destination. What is critical is for DMOs to understand that, tourists are looking forward to satisfy some need, hence it is not the development of tourist attractions that should be their primary concern, but the ability of those attractions to meet the needs of the tourists. Furthermore, much as it has been observed that destinations are moving towards promoting several generic attractions as opposed to focusing on a few popular attractions, it would be more plausible if attractions were developed with a multipurpose agenda in mind. For example, since results show that a significant number of Australians visit British churches to enhance filial ties, it would be reasonable for the DMO in the United Kingdom to encourage such attractions to develop or add family-friendly facilities to their structures.

The study has limitations that need to be pointed out. First, the study used secondary data. The results would have been more robust if primary data were collected from tourists. It should also be noted that much as the two destinations examined in the study publish comprehensive data on their tourism sectors annually, some important information such as promotion costs and details on strategic partnerships with marketing agencies, which the destinations might consider sensitive, is not made available to the public. Thus the information accessed for analysis, though comprehensive, was less than desirable. Moreover, a deeper analysis would have been taken and perhaps more relevant findings revealed if other dimensions such as average length of stay, first-time vis-à-vis repeat visitors, etc. were taken into consideration. This could form the basis for further studies on the topic.

\section{References}

Aspridis, G., Sdrolias, L., Kimeris, T., Kyriakou, D., \& Grigoriou, I. (2015). Visitor attraction management: is there space for new thinking despite the crisis? The case of Buckingham palace and the museum of acropolis. In V. Katsoni (Ed.), Cultural Tourism in a Digital Era: First International Conference IACuDiT Athens. Cham: Springer International Publishing.

Awaritefe, O. (2004). Motivation and Other Considerations in Tourist Destination Choice: A Case Study of Nigeria. Tourism Geographies, 6(3), 303-330.

Backman, K., Backman, S., Uysal, M., \& Sunshine, K. 1995). Event tourism: An examination of motivations and activities. Festival Management and Event Tourism, 3(1), 15-24.

Becken, S. (2005). The role of tourist icons for sustainable tourism. Journal of Vacation Marketing, 11(1), 21-30.

Benckenendorff, P., \& Pearce, P. (2003). Australian tourist attractions: The links between organisational characteristics and planning. Journal of Travel Research, 42, 24-35. 
Bloomingdale's Loves Great Britain. (2013, September 3). Business Wire. Retrieved from: http://www.businesswire.com/news/home/20130903005921/en/Bloomingdale\%E2\%80 $\% 99$ s-Loves-Great-Britain. (Accessed $14^{\text {th }}$ October, 2017).

Bull, A. (1991). The economics of travel and tourism. Melboune: Pitman.

Cha, S., McCleary, K. W., \& Uysal, M. (1995). Travel motivations of Japanese overseas travelers: A factor-cluster segmentation approach. Journal of Travel Research, 34(1), 33-39.

Connell, J., Page, S.J., \& Meyer, D. (2015). Visitor attractions and events: Responding to seasonality. Tourism Management, 46, 283-298.

Crompton, J. L. (1979). Motivations for pleasure vacation. Annals of Tourism Research, 6(4), 408-424.

Dann, G. (1977). Anomie, ego-enhancement and tourism. Annals of Tourism Research, 4(4), 184-194.

Doran, R., Larsen, S., \& Wolff, K. (2015). Different but similar: Social comparison of travel motives among tourists. International Journal of Tourism Research, 17, 555-563.

Edelheim, J. R. (2015). Tourist attractions: from object to narrative. Bristol: Channel View Publications.

Fodness, D. (1994). Measuring tourism motivation. Annals of Tourism Research, 21(3), 555581.

Garrod, B., Fyall, A., \& Leask, A. (2002). Scottish visitor attractions: managing visitor impacts. Tourism Management, 23(3), 265-279.

Goeldner, C. R., McIntosh, R. W., \& Ritchie, J. R. B. (2000). Tourism: Principles, practices, philosophies (8th ed.). Toronto: John Wiley \& Sons.

Gunn, C.A. (1972). Vacationscape - Designing Tourist Regions. Texas: University of Texas.

Hilton Resorts and Hotels. (2017). Travel trends: the state of US passport use. Retrieved from:http://hiltonglobalmediacenter.com/assets/HILT/images/campaign/Passport_Proje ct/Assets/Hilton_Blue_Paper_State_of_US_Passport_Use_August2017.pdf. (Accessed 18th October, 2017).

Huang, S., \& Hsu, C.H.C. (2009). Effects of travel motivation, past experience, perceived contsraint, and attitude on revisit intention. Journal of Travel Research, 48(1), 29-44.

Huang, W., Beeco, A., Hallo, J.C., \& Norman, W.C. (2016). Bundling attractions for rural development. Journal of Sustainable Tourism, 24(10), 1387-1402.

Ioannides, D. \& Timothy, D. (2010). Tourism in the United States: An introduction. New York: Taylor and Francis.

Iso-Ahola, S.E. (1982). Toward a social psychological theory of tourism motivation: A rejoinder. Annals of Tourism Research, 9(2), 256-262.

Kim, S. S. \& Lee, C. L. (2003). Push and pull relationships. Annals of Tourism Research, 29(1), $257-260$.

Kim, Y. J., Pearce, P. L., Morrison, A. M., \& O’Leary, J. T. (1996). Mature versus youth travelers: the Korean market. Asia Pacific Journal of Tourism Research, 1(1), 102-112.

Klarić, Z. Bottom-up approach to classification of tourist attractions: A case study of Croatia. Tourismos: An international multidisciplinary journal of tourism, 11(1), 01-20.

Weaver, D. B. (2006). Sustainable tourism: Theory and practice. Oxford: ButterworthHeinemann.

Leask, A. (2010). Progress in visitor attraction research: Towards more effective management. Tourism Management, 31(2), 155-165.

Lee, U., \& Pearce, P. (2002). Travel motivation and travel career patterns. Proceedings of $1^{s t}$ Asia Pacific Forum for Graduate Students Research in Tourism, 17-35.

Leiper, N. (1990). Tourist attraction systems. Annals of Tourism Research, 17(3), 367-384.

Lenz, H. (2016). Germany and VisitBritain Campaigns. London: British Tourist Authority. 
Leong, A.M.W., Yeh, S., Hsiao, Y., \& Huan, T.T.C. (2015). Nostalgia as travel motivation and its impact on tourists' loyalty. Journal of Business Research, 68(1), 81-86.

Lew, A. A. (1987). A framework of tourist attraction research. Annals of Tourism Research, 14(4), 553-575.

Lohmann, M. (2015, March). Tourism Trends Germany. Paper presented at the ITB Berlin Travel Fair, Berlin.

MacCannell, D. (1976). The tourist: A new theory of the leisure class. Berkeley, CA: University of California Press.

Mayling, S. (2016). VisitBritain woos Down Under with £1.6m campaign. TravelGBI. Retrieved from: http://www.travelgbi.com/articles/120236/visitbritain-woos-downunder-with-16m-campaign. (Accessed $20^{\text {th }}$ October, 2017).

McIntosh, R. \& Goeldner, C. (1990). Tourism: Principles, practices, philosophies, $6^{\text {th }}$ ed.). Toronto: John Wiley \& Sons.

McKercher, B. (2016a). Towards a taxonomy of tourism products. Tourism Management, 54, 196-208.

McKercher, B. (2016b). Do Attractions Attract Tourists? A Framework to Assess the Importance of Attractions in Driving Demand. International Journal of Tourism Research, 19(1), 120-125.

McKercher, B., \& Chan, A. (2005). How special is special interest tourism? Journal of Travel Research, 44(1), 21-31.

McKercher, B., \& Koh, E. (2017). Do attractions "attract" tourists? The case of Singapore. International Journal of Tourism Research, 19(6), 661-671.

Middleton, V. T. C., \& Clarke, J. (2001). Marketing in travel and tourism. Oxford: Butterwoth-Heinneman.

Mill, R. C., \& Morrison, A. M. (1985). The tourism system: An introductory. New Jersey: Prentice Hall.

Moscardo, G., Morrison, A., Pearce, P., Lang, C-T., \& O’Leary, J. (1995). Understanding vacation destination choice through travel motivation and activities. Journal of Vacation Marketing, 2(2), 109-122.

Moutinho, L. (2001). Consumer behavior in tourism. European Journal of Marketing, 21(10), $5-44$.

Norris, D. F. (2003). If we build it, they will come! Tourism-based economic development in Baltimore. In D. R. Judd (Ed.), The infrastructure of play (pp. 125-167). New York: M.E. Sharpe.

Pearce, P.L. (1982). Perceived changes in holiday destinations. Annals of Tourism Research, 9(2), 145-164.

Pearce, P. L. (1988). The Ulysses Factor: Evaluating visitors in tourist settings. New York: Springer-Verlag.

Pearce, P. L. (1991). Analysing tourist attractions. Tourism Studies, 2(1), 46-55.

Pearce, P. L. (2005). Tourist behavior: Themes and conceptual schemes. Clevedon: Channel View Publications.

Pearce, P. L. (2011). Travel motivation, benefits and constraints. In Y. Wang \& A. Pizam (Eds.), Destination marketing and management: theories and applications (pp. 39-52). Wallington: CABI.

Pearce, P. L., \& Lee, U.-I. (2005). Developing the travel career approach to tourist motivation. Journal of Travel Research, 43(3), 226-237.

Plog, S. (1974). Why destination areas rise and fall in popularity. The Cornell Hotel and Restaurant Administration Quarterly, 14(4), 55-58.

Plog, S. (1987). Understanding psychographics in tourism research. In J.R.B Ritchie \& C.R. Goeldner (Eds.), Travel, tourism and hospitality research: A handbook for managers and researchers (pp. 203-213). New York: John Wiley \& Sons. 
Plog, S. (2001). Why destination areas rise and fall in popularity: An update of a Cornell Quarterly classic. The Cornell Hotel and Restaurant Administration Quarterly, 42(3), 13-24.

Ram, Y., Björk, P., \& Weidenfeld, A. (2016). Authenticity and place attachment of major visitor attractions. Tourism Management, 52, 110-122.

Richards, G. (2002). Tourism attraction systems: Exploring cultural behavior. Annals of Tourism Research, 29(4), 1048-1064.

Rosentraub, M. S., \& Joo, M. (2009). Tourism and economic development: Which investments produce gains for regions? Tourism Management, 30(5), 759-770.

Ryan, C. (1998). The travel career ladder: An appraisal. Annals of Tourism Research, 25(4), 936-957.

Sharpley, R. (2009). Tourism development and environment: Beyond sustainability? London: Earthscan.

Sun, M. (2013). Analysis of Chinese travel blogs of New Zealand (Doctoral dissertation). Hamilton: University of Waikato. Retrieved from https://researchcommons.waikato.ac.nz/ (Accessed 7 October, 2018).

Sung, H., Morrison, A., \& O'Leary, J. (2000). Segmenting the adventure travel market by activities: from North American providers' perspective. Journal of Travel and Tourism Marketing, 9 (40), 1 -20.

Swarbrooke, J. (1995). The development and management of visitor attractions. Oxford: Butterworth-Heinemann.

Swarbrooke, J. (1999). Sustainable tourism management. Wallington: CABI Publishing.

Swarbrooke, J. (2002). The development and management of visitor attractions $\left(2^{\text {nd }}\right.$ ed.). Oxford: Butterworth-Heinemann.

Telegraph Travel (2017). 'Humourless and nude': The truth about German holidaymakers. (2017, February 28). Retrieved from: https://www.telegraph.co.uk/ (Accessed 5 October, 2018).

The Business Traveler (2018). Why Chinese tourists come to the UK. Retrieved from https://www.businesstraveler.com/opinion/chinese-tourists-come-uk/. (Accessed 4 October, 2018).

Tourism New Zealand. (2017). Wellington: New Zealand Tourism Board. Retrieved from: http://www.tourismnewzealand.com (Accessed 5 September, 2017).

Truchet, S., Piguet, V., Aubert, F., \& Callois, J.-M. (2016). Spatial influence of attractions on tourism development. Tourism Geographies, 18(5), 539-560.

VisitAberdeenshire. (2017). Being German Ready: Business Opportunities Guide. Retrieved from https://www.visitabdn.com/assets/ (Accessed 4 October, 2018).

VisitBritain. (2017).Official Statistics. Retrieved from: https://www.visitbritain.org (Accessed 10 October, 2017).

VisitScotland. (2018). Insight Department: Australian visitors to Scotland. Retrieved from https://www.visitscotland.org/ (Accessed 4 October, 2018).

Wong, K. M., \& Musa, G. (2014). Retirement motivation among 'Malaysia My Second Home' participants. Tourism Management, 40, 141-154.

Wu, M-Y., \& Pearce, P.L. (2014). Chinese recreational vehicle users in Australia: A netnographic study of tourist motivation. Tourism Management, 43, 22-35.

Zhang, Y., \& Peng, Y. (2014). Understanding travel motivations of Chinese tourists visiting Cairns, Australia. Journal of Hospitality and Tourism Management, 21, 44-53. 


\section{Author Biography}

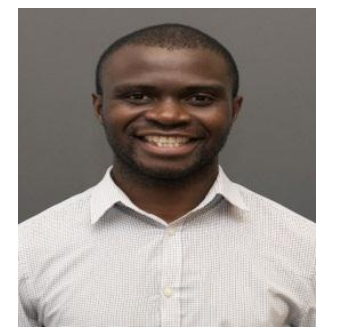

Zandivuta Kankhuni is a $\mathrm{PhD}$ student in the School of Hotel and Tourism Management at the Hong Kong Polytechnic University, Hong Kong. He holds a BSc Hospitality Management from Mzuzu University, Malawi and a Master of Management (Tourism) from Hebei University, People's Republic of China. He has special research interests in destination competitiveness and tourism marketing. Zandivuta is a lecturer in the Department of Hospitality Management at Mzuzu University, Malawi.

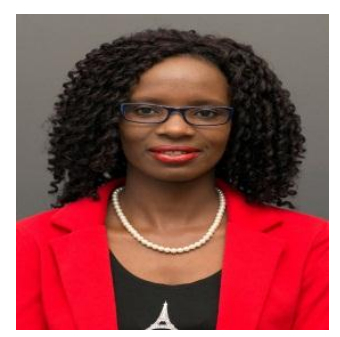

Cecilia Ngwira is a PhD student in the School of Hotel and Tourism Management at the Hong Kong Polytechnic University, Hong Kong. Cecilia holds a BSc in Tourism Management from Mzuzu University, Malawi and a Master of Management (Tourism) from Hebei University, People's Republic of China. She has special research interests in cultural heritage tourism and tourism development. Cecilia is a lecturer in the Department of Tourism Management at Mzuzu University, Malawi. 